\title{
Asbestos and Salamander in India
}

\author{
Péter-Dániel Szántó \\ Universiteit Leiden, Leiden, The Netherlands \\ p.d.szanto@hum.leidenuniv.nl
}

\begin{abstract}
The present paper, an homage to B. Laufer's "Asbestos and Salamander" (1915), adds South Asia to the story of a remarkable Eurasian cultural meme meant to explain the presence of fire-proof cloth after its manufacturing technology was forgotten, namely that asbestos was the fur of a mythical animal. I argue that none of our Sanskrit dictionaries contain the correct meaning of the term agniśauca, which does indeed mean asbestos. The widely shared motif explains why in Sanskrit literature too we have animals (a nondescript mrga) by the same name. I examine textual passages from kārya, purānas, as well as Buddhist sūtras and śāstras, to elucidate this topic. I also cite some evidence that in the period between the 9 th and the 11th c. some areas of India still possessed knowledge of asbestos manufacturing. However, as for where and when the correlation was first made, I must leave the question open.
\end{abstract}

\section{Keywords}

agniśauca - asbestos - South Asian material culture - Sanskrit lexicography - kārya purāna - Buddhism

\section{1 \\ Introduction: What Is agniśauca?}

In vain would a person curious about details (and prone to get lost in them) look for the true meaning of the Sanskrit word agniśauca in the hefty lexicographical aids we have at our disposal. The Great and the Short Petersburg Dictionaries contain only two synonyms, vahniśuddha and vahnidhauta, as adjectives 'rein wie [/das] Feuer' to some kind of cloth. Monier-Williams has agniśauca as 'a fine muslin garment'. Apte sees it as an adjective, 'bright as fire; purified by fire'. The Pune Dictionary is more generous: from here we gather not 
only that agniśauca (and its synonym analaśauca) can describe a kind of cloth (vastra, vāsas, vasana, aṃśuka, cirra), but that it also occurs as a noun, and that it can also refer to some kind of deer (enaka, sārañga), which is in the curious habit of cleansing itself in fire.

I gave away the solution in the title, because I could not resist the temptation of thus paying homage to a masterful essay by Berthold Laufer (1915) which for me not only provided the solution to a seemingly minor philological problem, but also opened a vast vista, a cultural meme shared across the Eurasian landmass from Late Antiquity into the Early Modern. The two meanings are related: the agniśauca cloth cleansed in fire is asbestos and the agniśauca animal washing itself in fire is what cultures on the western side of Eurasia once knew as the mythical salamander, but which in India appears either as a nondescript beast (mrga) or some sort of deer.

The quest for the meaning of the word agniśauca for the present author started in 2013 with a then unknown manuscript fragment, a passage from a tantric Buddhist ritual manual. ${ }^{1}$ The paragraph in question described a ritual meant to protect a polity. The ritualist (mantrin) should visualise in the sky a blazing five-pronged sceptre (vajra), whose rays sweep over the polity he intends to protect, burning all its ails and troubles but at the same time leaving it and its inhabitants intact. The author says that this process is in the manner of the agniśauca cloth (agniśaucavastranyāyena). This expression made me pause and after having realised that the meanings provided by our standard references are unsatisfactory, it gave me a few good weeks' worth of delightful if at times troublesome research experience.

Let us first look at the loci recommended by the dictionaries. ${ }^{2}$

The Great Petersburg Dictionary is silent for agniśauca, but does contain an entry for a synonym, vahniśuddha. ${ }^{3}$ It is interpreted as an adjective, 'rein wie

1 Now published in Szántó (2015a). Also see a somewhat embarrassing addition I published privately here: https://www.academia.edu/14142655/Addenda_to_2015a_Minor_Vajrayāna_Text s_III. It is now clear that the author of this work is Divākaracandra, who flourished in the second half of the 11th c., before $1101 \mathrm{CE}$.

2 I wish to note that not all references were available to me and even from among those that I have managed to locate I will discuss only the more important ones. The two Sanskrit-Sanskrit dictionaries I could check, the Vācaspatya (Bhațțācārya 1873) and the Śabdakalpadruma (Vasu and Vasu 1886), do not contain relevant entries.

3 Böhtlingk and Roth (1871: 873). 
Feuer', and only a single work with numerous loci is referenced. This is the socalled Näradapañcarātra. ${ }^{4}$ The editor of this text enthusiastically introduces it as "one of the oldest, if not the very first, specimen of Vaishṇava literature in Sanscrit." However, in a brief but very useful overview, Farquhar ${ }^{5}$ dissected the text and argued that books I and II, the loci the Great Petersburg Dictionary used, are later parts. He reasoned that these books display Rādhā-Vallabhī elements, which is to say that they must date from later than $1585 \mathrm{CE}$, which is when the said school was founded. ${ }^{6}$ This part of the text then is a rather late one.

All the occurrences cited by the dictionary are adjectives to a kind of cloth (vastra or aṃsuka): in 1.7.47 a charioteer is decorated with vahniśuddhāmśuka, 1.8.5 describes chapels in Nārada's áśrama decorated with the same, in 1.11.9 we have the same as a gift of Brahmā, in 1.11.28 the same but now in a pair as a gift of Agni, in 1.12.19 cloths numbering three lakhs are ornamenting a divine chariot, three verses later (a locus not noted by Böhtlingk and Roth) we have the same ornamenting a youth in the chariot and we are told that its colour is yellow ( pita), in 1.14.6o it functions as clothing, in 2.4.4 as divine clothing, and in 2.4.24 we find the cloth again in a pair and as a gift of devotion. ${ }^{7}$

The Short Petersburg Dictionary contains an entry for yet another synonym, vahnidhauta. ${ }^{8}$ This too is given as an adjective, 'rein wie das Feuer' and the reference sends us to Weber. ${ }^{9}$ Here the word is revealed to come from a manuscript of one of the recensions of the Siṃāsanadvātrimsíikā, a popular narrative work centred on the figure of King Vikramāditya. We read that the king is sent a throne accompanied by a vahnidhauta cloth. The recension the aforementioned manuscript is part of is the Jaina one, for which Edgerton argues that it cannot be earlier than the $13^{\text {th }} .^{10}$

\footnotetext{
$4 \quad$ Banerjea (1865).

$5 \quad$ Farquhar (1926).

6 Farquhar (1920: 318).

7 Talking of vastra as a pair or using the dual is explained by the classical custom of giving cloth in twos. When worn, these are known as the uttariyam and the adhovāsas or any of their synonyms. Henceforth I will ignore the numeric issue. It is worth noting that cloth was not always worn, but sometimes functioned as currency along with silver. This was noted by the Korean monk Hye-Ch'o (Chinese Huichao) during his travels to the West between 723-729 CE, see Yang et al. (1984: 43).

8 Böhtlingk (1886: 51 ).

9 Weber (1878: 293).

10 Edgerton (1926: liii).
} 
In the additions to the Short Petersburg Dictionary, ${ }^{11}$ we find a hesitant interpretation: 'etwa: ein Gewand von Byssus oder Nesseltuch', with the source given as the Buddhist Kärandaryūhasūtra. This locus was perhaps suggested by Monier-Williams, but since Schmidt provides a precise reference ([p.] 78 , [1.] 23), it could have been the case that he found it himself. As we will see, Schmidt was right to exercise caution when proposing the meaning.

\section{3}

\section{Monier-Williams}

Monier-Williams noted only one source for the word, the Buddhist Kärandavyūhasūtra. ${ }^{12}$ He most likely availed himself of Satyavrata Sāmaśramī's 1879 Calcutta edition, as did Schmidt. ${ }^{13}$ This is based on a Nepalese manuscript from the late 12 th c. and is full of corruptions. ${ }^{14}$ It is clear to me that the interpretation 'a fine muslin garment' must be that of the then Boden Professor, because the Great Petersburg Dictionary, a constant source of inspiration for MonierWilliams (to put it diplomatically), is silent on this point. However, I think that the provided English equivalent was mere guesswork on his part.

The word occurs in a list of gifts the bodhisattva Sarvanīvaraṇaviṣkambhin brings to a preacher (dharmabhānaka) residing in Benares: ${ }^{15}$

[...] for worship he gathered divine (i.e. splendid, quality) parasols, divine sandals, [...] Benares cloths, agniśauca cloths, and all kinds of other cloths, $[\ldots]$.

Monier-Williams must have reasoned that since immediately before the word in question we have the prized loom-work of Benares weavers, ${ }^{16}$ it too must

\footnotetext{
11 Schmidt (1928: 7).

12 Monier-Williams (1899: 1309). This is in an appendix to the second edition. On the relationship between the Petersburg dictionary and Monier-Williams, see Steiner (2020).

13 Samasrami (1879: 78). I have not seen the rare 1872 Serampore edition and Buddhadev Bhattacharya's 2016 edition is not available to me at present.

14 The rightfully maligned but pervasively available 'edition' by Vaidya is based on the Calcutta publication, as pointed out by Mette (1997: 164). Also see Studholme (2002: 16-17) citing an earlier assessment by Mette. Studholme's note on p. 162 cites Bendall who traced Sāmaśramī's manuscript which bears the date $1196 \mathrm{CE}$.

15 Samasrami (1879: 78-79), Vaidya (1961: 298): atha Sarvanīvaranavișkambhī (Samasrami:

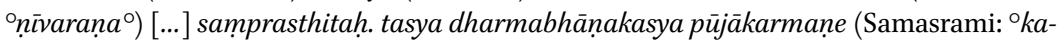
rmaṇo) divyāni chattrāṇi divyāni upānahāni [...] kāśikavastrāny agniśaucavastrāṇi ca anyāni ca vividhāni vastrāṇi [...] gṛhitvā yena Vārānnasī mahānagarì tenopajagāma.

16 This also became a generic term, as suggested by Ratnākaraśānti in his Sāratamā (Jaini
} 
mean some sort of fine garment. However, the passage does not reveal anything more than the fact that the agniśauca cloth was something prized and suitable for a fine gift.

The date of the Kärandaryūhasūtra is not a settled issue. Studholme ${ }^{17}$ proposes that it dates from as early as the late 4 th or the early $5^{\text {th }} \mathrm{c}$. This is also broadly the opinion of Mette, who edited the Gilgit fragments, which were penned before ca. $630 \mathrm{CE} .{ }^{18}$ Unfortunately, this passage does not survive in these early witnesses..$^{19}$ While it is not out of the question that the word agniśaucavastra was present in the early strata, I prefer to remain cautious until a proper critical edition is achieved or more early fragments are found. At least one early East Indian witness suggests that we should not be bold in positing its presence at the very inception, as here the word is not transmitted. ${ }^{20}$

The Tibetan translation dates from the late Imperial Period. ${ }^{21}$ For the word in question we find simply mas [=mes] bgru ba'igos, "cloth washed/cleansed in fire." The Chinese translation dates from $983 \mathrm{CE}$ and I will ignore it here, because we have earlier sources to discuss. ${ }^{22}$

1979: 196): kāśikavastram vārānaseyakam diryam vā. Note that divya does not necessarily suggest divine origin, $\mathrm{cf}$. the now somewhat antiquated informal English usage of 'divine'.

17 Studholme (2002: 14). He also proposes a Kashmiri provenance.

18 Mette (1997: 9). Mette and Sakuma (2017: xix-xx) has "either in the 6th century or the early part of the 7th century."

19 Mette (1997: 153) edits the passage from a late Nepalese manuscript. This is much better constituted than Samasrami's (and Vaidya's) text, but this does not make a difference for the matter at hand. In the most up-to-date overview of the Gilgit hoard, von Hinüber (2014: 107, based on information from Klaus Wille) pointed out a further fragment (parts of folios 62 and 63), which is now published by Mette and Sakuma (2017). I thank Klaus Wille for providing a transcript of this fragment, which does not contain anything relevant for the passage I discuss here.

20 This is an undated witness penned in Pāla style, National Archives Kathmandu 4-1631 = Nepal German Manuscript Preservation Project reel no. B 23/3, folio 74r. However, another, probably even older manuscript (National Archives Kathmandu 3-359 = Nepal German Manuscript Preservation Project reel no. A 39/5, dated Nepālasamvat $88=$ ca. $968 \mathrm{CE}$, folio 39r) does transmit it.

21 Tōhoku no. 116 (for the passage, see 236a). Roberts and Yeshi (2013: i.13) argue for a date between 815 and $824 \mathrm{CE}$. In their translation the word is mysteriously skipped.

22 T1050. The pervasive error that there existed two earlier translations, one from $270 \mathrm{CE}$ and one from $435^{-443} \mathrm{CE}$ is due to a misidentification, as pointed out by Studholme (2002: $9)$. 
As for Apte, ${ }^{23}$ here we are in a better position at least as far as the dating is concerned. He sends the reader to the Kädambari prose romance, or more precisely, to its latter part. The author of the Kādambarì is the famous Bānabhatța, who flourished in the first half of the 7 th c. However, the locus we are interested in is found in the second part, which was authored by his son, commonly known as Bhūṣaṇabhațta, after his father passed away leaving a masterpiece unfinished. This poet, via a protagonist acting as messenger, describes the eponymous heroine thus: ${ }^{24}$

citrạ̣ cedam! makaraketuhutabhujā dahyamānam apy agniśaucam ạ̣śukam iva nitarām nirmalībhavati lāvaṇyam.

That is to say:

But how strange! Although burnt by the fire (lit. 'the oblation eater') of Kāma (lit. 'the one with the crocodile ${ }^{25}$ banner'), her beauty becomes all the more spotless, just like the agniśauca cloth.

Translators of this passage offer the following interpretations: the cloth becomes whiter due to the expert handling of a washerman, ${ }^{26}$ or because it is purified by fire without any further explanation, ${ }^{27}$ or because it was purified by the fire-god Agni. ${ }^{28}$ Siddhacandra, the Jain commentator active at the court of Emperor Akbar (r.1556-1605 CE) is not very helpful either, as his gloss is quite

\footnotetext{
23 Apte (1957: 17).

24 I quote the text from the edition of Peterson (1889: 252). Punctuation mine.

25 For this meaning of makara and not 'dolphin', etc., see Vogel (1957: 561-564).

26 Kane (1913: 144): "[...] like a piece of cloth (which becomes whiter) when purified by heat (at a washerman's). agninā śaucam yasya."

27 Scharpé (1937: 145): "En wat wonder is, is dat haar lichaamsglans, niettegenstaande deze door het liefdevuur verschroeid wordt, toch volkommen vlekkeloos blijft: een kleed gelijk, dat door het vuur gereinigd is." "And what is a miracle is that the radiance of her body, in spite of the fact that it is being burned by the fire of love, nonetheless remains completely spotless, like a garment that has been purified by fire."] Rajappa (2010: 258): "But how very strange indeed, the more the fire of Manmatha burns the more flawlessly brilliant her beauty becomes, like the cloth purified by fire." I do not have access to Vasant Ramachandra Nerurkar's 1915 translation (Bombay: Oriental Publishing Company).

28 Layne (1991: 248): "Strangely enough, the sheen of her body, scorched by the Makarabannered God's fire, remains completely spotless, like a silk garment that has been purified by Agni."
} 
feeble and ultimately wrong: the image is not an utprekșa (poetic fancy) but an upama $\bar{a}$ (simile). ${ }^{29}$ The slightly later and otherwise very learned Arjunapandita is also unobliging, as he simply tells us about the standard property of the cloth: it does not burn to ashes but becomes purer when thrown into fire. ${ }^{30} \mathrm{~A}$ modern Sanskrit commentator tells us that according to tradition, in days of yore there was such a cloth, which was purified in fire. ${ }^{31}$ Bhūṣana's image, however obscure, remained celebrated even in late mediaeval times. ${ }^{32}$

\section{The Pune Dictionary}

I shall examine only a few of the works mentioned by the Pune Dictionary under the headword agniśauca ${ }^{33}$ and analaśauca ('purified by heat'), ${ }^{34}$ a synonym. I list the occurrences in chronological order adding data from related sources such as commentaries or secondary literature.

The Märkandeyapurāna (ca. 8th c.) passage we can see in the quotation in n. 31 here, because the Durgāsaptaśatì (or Devīmāhātmya) is part of this work. ${ }^{35}$ However, the passage is not very revealing: we come to know only that the pair of cloths was the gift of Agni to the demon Śumbha. ${ }^{36}$

29 Parab and Paṇsîkar (1916: 441): kìdṛśam lāvaṇyam? utprekṣate-agninā śaucam śuddham aṃśukaṃ vastram iva. Mathurānāth Śāstrī only addresses a grammatical point in his modern gloss, for which see Parab (1948: 511).

3o Srivastava (1979:45): agniśaucam ạ̣śukam - agninikṣiptaṃ abhasmībhavat pratyutanirmalam bhavati. On the relative date of this author, see pp. 37-40 of the introduction. See pp. 1-2 of the introduction for the other possible names of Bhūṣaṇa.

31 Miśra (1973: 24): agniśaucam aṃśukam-pāvakadvārā saṃskaraṇȳyạ vastram. śrūyate-pūrvam etādṛ́am api vastram yad vahninā samskṛtam abhūt. tathā ca Durgāsaptaśatyām "vahnir api dadau tubhyam agniśauce ca vāsasī" iti. yathā yathā kāmāgninā dahyate, tathā tathā agniśaucam vastram iva Kādambaryā lāvanyam nirmalībhavatīti bhāvah.

32 It is quoted, or better said paraphrased, by Pūrṇasarasvatī (ca. late 14th to/or early 15th c.) in his commentary called Rasamañjari to the Mālatìmādhava of Bhavabhūti (Mahādēva Śāstrī 1953: 511; for the date, see the introduction, p. xxiv).

33 Ghatage 1977:390.

34 Joshi 1991: 218 o.

35 The date is proposed by Yokochi (2004: 8), substantiated in n. 42 on pp. 21-23.

36 Coburn (1991: 56) translates (inadequately) as follows: "And Agni gave you two garments purified by the fire himself." I thank Somdev Vasudeva who pointed out to me that this locus is discussed in Ray (1917: 184-185, 220-221) and that the author of this study did in fact posit that the cloth in question is asbestos. However, the path through which he arrived to this hypothesis requires several leaps of faith, see pp. 184-185: "The Mārkandeya 
Abhinanda's Rāmacarita (middle of the 9th c.) describes a multitude of agniśaucāmśuka tents which glow all the brighter when purified by the fire that engulfs Lañkā (23.3cd). ${ }^{37}$

Ratnākara's epic, the Haravijaya (second half of the gth c.), mentions the miraculous cloth twice, in verses 28.83 and $30.86 .^{38}$ In the first instance we are told that the cloth's purification in fire takes place gradually. The gloss of Alaka, the 12th-century commentator, is perhaps more noteworthy, because here the word seems to be treated as a technical term. ${ }^{39}$

Purān furnishes among others a remarkable statement regarding an incombustible cloth apparently much prized in ancient times. It was a wearing apparel which could be purified by fire. I have not found any reference to this kind of fabric in any other work. [...] I give the explanation of agni-śuchi vāsa of the Chandī Māhātmya of the Mārkandeya Purān for what it is worth. I shall, however, draw the reader's attention to the remarkable conception of the Māhätmya, describing how the valiant Asuras were killed in successive battles by a lady with her women soldiers fighting on behalf of the Suras. I take the Asuras, as many do, to have been Assyrians, among whom there were Kālakā and Kālakeyā troops (Chap. 80). The latter are taken to have been the Chaldeans with whom the IndoAryans were acquainted. It is well known that the ancient Egyptian priests used to value incombustible fabrics made of asbestos. [...] If we treat the account as a piece of chronicle, and I do not know why we should not, we can understand how the Asura king got the incombustible dress." More sober and to the point is the passage on p. 221: "That the robe was rare and highly prized is evident from the context; and whatever the stuff was, it was neither vegetable nor animal. The only fibrous material indestructible by fire and suited for spinning is the mineral asbestos, especially the variety known as Amianth. Formerly in Europe asbestos was mixed with flax before spinning, the vegetable fibre being then eliminated from the finished fabric by calcination. At the present time asbestos is spun direct into yarn, and the yarn is woven into fabrics as incombustible table-cloths, and garments for fire-brigade men, etc. It is quite likely that the 'fire-purified' garment was no other than a similar stuff. A fibrous variety of asbestos is found in many parts of India, and ropes are made in Afghanistan. Whether the incombustible robe was made somewhere in India or imported from Egypt where priests used to wear asbestos cloth remains an open question." To the last sentence, Ray adds this note: "The word asbestos if Sanskritized would be perhaps Asprishț — untouched (by fire). Asbestos has a similar derivation."

37 Rāmaswāmī (1930: 198): dhautatvam āsādya parạ̣ virejus tatrāgniśaucāṃśukamaṇdapaughăh ||. This Abhinanda was commonly associated with Devapāla of the house of Pāla and thus assigned to the early gth c., see the lengthy introduction in the referenced volume. However, more recently it has been accepted that the patron was one of Devapāa's sons and that therefore Abhinanda's poetic activity falls in the middle of the gth c., see Tubb (2014: 388) citing Kosambi.

38 The Pune Dictionary notes only the first.

39 Durgâprasâd and Parab (189o: 368): agniśaucaṃ nāma sicayaṃ yasyāgnimadhye śuddhị̣. Also cf. n. 43, where we have ${ }^{\circ} \overline{\text { kkhyam}}$. For the dates of Ratnākara and Alaka (or Allața), see Pasedach (2017: 1-3, 14). 
The Bālarāmāyaṇa of Rājaśekhara (early 1oth c.) again simply alludes to the motif that the agniśauca cloth becomes clean when burnt by fire (act 8, stanza $51) \cdot{ }^{40}$

In Trivikramabhatța's Nalacampū (early 1oth c.) the cloth once again figures in a list of gifts, this time by queen Priyangumañjari to the sage Damanaka, who politely refuses to accept them with a series of clever if offensive puns. It is noteworthy that the queen seemingly calls the cloth Chinese cloth (cinammśuka), normally a term denoting silk. ${ }^{41}$ I suspect that the author did not think that the cloth was Chinese import, but that he needed to use the word for a pun in the sage's refusal (apācinam vāsas). Just as Benares cloth too became a generic term (see n. 16 here), ciñamśuka here seems to mean silk or silky garment. As we will see later, the agniśauca cloth is indeed reminiscent of silk, but it is originally not a Chinese invention and was not manufactured in China in the pre-Mongol period. ${ }^{42}$

40 Govinda Deva Śástri (1869: 237). Vidyasagara's gloss (1884: 529-530) is unhelpful for the matter at hand. One eagerly awaits H.N. Bhatt's work to be published. For the dates, see McCrea (2014: 416) citing De.

41 Tripāthī (1976: 157): [...] analaśaucam cīnāmśsukapaț̣aparidhānayugalam [...]. The commentator Caṇdapāla has nothing interesting to say on the word. For the date of Trivikramabhațta, see Bhandarkar (1907-1908: 28). I also consulted an older edition (S'arma 1932), but found nothing worth reporting.

42 I became aware of and gained access to the following learned note only after submitting the present paper for peer review. In Doshi and Chandra (1980: 40) we read: "A very interesting reference to asbestos cloth appears in the Parisista-parvan. While describing a Jaina monk, Hemacandra observes that by his flaming fire of penance he reduced the sins of his karma to ashes and purified his soul like the asbestos cloth which is cleansed by fire (agnisaucamsuka). It is interesting to note here that the Vaijayanti also mentions a stuff which is spelt as agnigauca, ga being misread for correct sa. It is further mentioned that it was decorated with floral meanders (vakravalli). It is remarkable that in old Chinese literature asbestos cloth is named as huo huan-pu 'the cloth that can be cleaned by fire', which was correctly translated into Sanskrit as agnisauca. Pliny (XIX, 1 (4), 19 seq.) ascribes its origin to India. According to Chinese sources it was obtained from the hair of an animal which lived in fire and died in water, though later on it came to be known as 'stone wool'. Whatever the source of the origin of asbestos cloth might have been in ancient times, there is little doubt that in the tenth-eleventh century China exported the stuff to India. This is further supported by a reference in the Nalacampu of Trivikrama Bhatta (Bombay, 1931) written in the early tenth century. Rsi Damanaka addresses Damayanti's mother thus: "Please receive this pair of Chinese silk (cinamsukapatta) that can be cleaned by fire (analasaucam), which is as white as a moonlight." Here the Chinese origin of asbestos cloth is quite clear." According to the article, the source of this note is Moti Chandra's monograph Costumes, Textiles, Cosmetics and Coiffure in Ancient and Mediaeval India (Delhi: Oriental Publishers, 1973) which I cannot access at present. While I do not agree with the author's statement about the cloth being Chinese import, I concur with the gen- 
Somewhat more intriguing are the loci in Somadeva's Kathäsaritsāgara (second half of the 11th c.). ${ }^{43}$ The word we are looking for appears in the author's reworking of the famous Nala narrative and it can be suspected that it was inserted by none other than Somadeva himself, because the cloth is not named thus in the previous versions. The Mahäbhärata simply calls it divyam (for which see n. 16 here), and Kșemendra's Bṛhatkathämañjarī terms it somewhat mysteriously as nāgāmśuka, perhaps suggesting that the underlying material was shed snakeskin. ${ }^{44}$ For Nala is gifted the agniśauca cloth by the snake Kārkoțaka, after it bites him in spite of the fact that our hero helped him. It is important to note that this help consisted of bringing the snake away from near a fire. Affixed to the complete English translation we find the following note, which will become relevant later: 45

In Prester John's letter quoted by Baring-Gould, Curious Myths of the Middle Ages, new edition, p. 43, we find: "In one of our lands, hight Zone, ${ }^{46}$ are worms called in our tongue Salamanders. These worms can only live in fire, and they build cocoons like silk-worms, which are unwound by the ladies of our palace, and spun into cloth and dresses, which are worn by our Exaltedness. These dresses, in order to be cleansed and washed, are cast into flames."

Willem Bollée's learned encyclopaedia of keywords in the Kathāsaritsāgara does not solve the mystery and according to his testimony neither does Nalini Balbir's French translation. ${ }^{47}$

eral point of the passage (which, however, is full of echoes of Laufer 1915), although I have reached a similar conclusion through another route.

43 Durgâprasâd, Parab and Paṇsikar (1915: 292, 294). The term occurs twice in the Alaṃkāravatïlambaka, taranga 6.351 (agniśaucākhyam [...] vastrayugaṃ) and stanza 411 (agniśaucam $[\ldots]$ vastrayugalam $)$.

44 S'ivadațta and Parab (1901: 539-540). Budhasvāmin's Bṛhatkathāślokasaṃgraha does not use this narrative. A later retelling of the story, Vāmanabhaț̣abāṇa's Nalābhyudaya (first half of the $1^{\text {th c.) }}$ reverts to the adjective of the Mahäbhärata, see Gaṇapati Sâstrî 1913: 43, stanza 8.16.

45 Penzer (1925: 245-246); emphasis in italics original. A convenient introduction to the figure of Prester John is Silverberg (1972). For Prester John's salamanders also see Büttner (2004: 52).

46 This does not make sense. The eclectic English antiquarian, the Reverend Baring-Gould (Penzer is referring to the second edition of his extremely popular work, that from 1867) is evidently amateurishly translating a to me unknown German translation of the Latin, which I saw in Büttner (2004: 52): In alia quadam provincia iuxta torridam zonam sunt vermes, [...]. For the only way iuxta torridam zonam can become "hight [=called] Zone" is if we posit a German intermediate along the lines of "nahe der heißen Zone."

Bollée (2015: 24): agni-śauca (not [in] M[onier-]W[illiams]) 'bright like fire' (Ghatage 
Kalhana's chronicle, the Rājataranginī (1148-1149 CE), contains three occurrences (of which the first is a synonym):48 hariṇi [...] hutāśaśaucā (5.15), agniśaucenakānām (6.364), agniśaucạ [...] sārañgah (8.3024). None of these three instances describe a cloth, or for that matter a worm, but some kind or deer or antelope. We are told that these animals clean themselves in fire. As noted by Stein (to 5.15), one of his manuscripts had the following marginal note: agniśaucānām mrgānāạm agninā lomaśuddhih agniśaucavasanavat, as well as hutāśenāgninā śaucạ̣ śuddhir yasyāḥ sā hutāśaśaucā. harinī mrgī iva yathā sā agnau prakșiptadehā satī suddhalomä bhavati tadvat. Which is to say that our learned glossator saw a parallel—but perhaps not a causal link — between the cloth and the fur of the animal (note: $m r g a$ ), inasmuch as both are cleansed in fire.

Hemacandra's (1088/9-ca. 1172 CE) Trișaștiśalākāpuruṣacaritra (1149-1162 $\mathrm{CE})$, one of his late works, describes in a prophecy that the subject Marīci will become purified by the fire of contemplation, just like the agniśauca cloth. ${ }^{49}$ Hemacandra uses a similar image in his Parisisistaparvan (1162-1172 CE)..$^{50}$

[1977]), snake gives garments called to Nala 56,351 (T[awney and] P[enzer] IV 245 "firebleached" with note; $\mathrm{O}$ [céan des ]R[ivières de ]C[ontes of N. Balbir] 642: "[vêtements] ils s' appellent 'purification par le feu'”). For a review, see Silk (2020). Bollée must have consulted an edition of Monier-Williams which did not contain the appendix (see n. 12 above). I should perhaps point out that the Purānic Encyclopaedia too was uninformative when discussing this locus (Mani 1975: 17).

48 For translations and notes, see Stein (1892-19oo: I.187, I.265, II.238). The text and notes are in III.72, 104, 277. Stein also refers to the Brahmavaivartapurāna, which I read in a later print with a slightly different stanza numeration (Marāțhe and Rānaḍe 1935). This is a rather late text. Here, as in the Näradapañcarätra, too we find the fire-cloth as ornaments on houses and chariots: vahniśaucāmśukai ramyaih [...] viräjitān [...] gṛhān (p. 449), ratham [...] sūkșmakāṣāyavastreṇa vahniśuddhena bhūṣitam (p. 459), ratham [...] vahniśuddhāmśsukānvitam (p. 46o). Perhaps the only noteworthy instance is vasanam vahniśaucam ca nirmitạ̣ Viśvakarmaṇā (p. 474), suggesting divine origin, the work of Viśvakarman.

49 Śrīcaraṇavijaya (1990: 144), stanzas 1.6.375-376: dukūlam iva pañkena niḥśvāseneva darpaṇah | karmaṇā malino 'muṣya jōvah samprati varttate || śukladhyānāgnisamyogād agniśaucam ivāmśsukam |jātyam suvarnam iva ca sa kramāc chuddhim eșyati ||. This is translated in Johnson (1931: 352-353) as: "Now, his soul goes stained with karma like a fine cloth with mud, or a mirror by the breath. He will attain enlightenment gradually from contact with the fire of pure meditation, like a cloth pure from fire, like pure gold."

50 Jacobi (1891: 182, 1932: 166), stanzas 6.90-91: sa khaḍadhārātīkṣnena vratena vratinām varạ̣ | ātmano dārayām āsa dāruṇān karmakaṇțakān || tapogninātidīpreṇa dagdhvā karmamahāmalam | agniśaucāmśukam iva sa ātmānam aśodhayat ||. Fynes (1998: 132): "An excellent monk, with a vow of asceticism as sharp as sword, he tore out the dreadful thorns of karma from his soul. The brightly flaming fire of his asceticism burnt the heap of dirt 
Govardhana's (ca. $1200 \mathrm{CE}$ ) Āryāsaptaśatī builds a simile around our word in a stanza (466) that merits quotation in full:51

yat khalu khalamukhahutavaha-

vinihitam api śuddhim eva param eti |

tad analaśaucam ivāmensukam

iha loke durlabham prema \|

The published English translation interprets this as follows: ${ }^{2}$

That supreme love, which obtains purity when falling into the fire of a rogue's mouth, is as rare to find here in this world as a blouse that becomes white in fire.

The translator ventures to explain the poetic image, in my view unsuccessfully, in a note. ${ }^{53}$ Another translation, in an unpublished thesis is better: ${ }^{54}$

That which itself truly attains purity, even when placed in the fire of a wicked person's mouth ... that is highest love-difficult to obtain here in this world, like a garment (which obtains) cleansing from burning.

which was his karma, and he purified his soul, like a white cloth purified by fire." For the dates, see Jacobi (1891: 11), citing Bühler (1889). Also see n. 42 here.

51 Durgāprāsad, Parab and Paṇs'îkar (1934: 191). Ananta, the commentator is not very helpful for our problem. He merely notes that we know of such a cloth from Purānas: vahner analaśaucam vastradvayam astīti purānaprasiddhị̣. He is most likely referring to the Mārkandeyapurāna, see n. $3_{1}^{1}$ here. A 19th-century commentator is somewhat more fanciful, imagining the cloth as made of gold fibre or as being incombustible because of some divine nature, see Misra (1931: 233): [...] analena agnidāhena śuddhaṃ pūrvarūpādhikarūpam aṃśukam vastram suvarṇasūtramayam yadvā 'gninā 'dāhyam devalokaprasiddham $\operatorname{tad}[\ldots]$.

$5^{2}$ Hardy (2009: 183).

53 Hardy (2009: 305): "Just as the blouse turns into black ashes, a love that is mentioned or talked about by a rogue becomes tainted and impure. This may be a general comment: as soon as a love-affair becomes public knowledge and is being gossiped about, it can hardly survive. Or specific, as censure of an unfaithful lover: don't talk about "love" to me, in your mouth known for its lies the word itself becomes dirty." Emphasis in bold original. It should be mentioned that these were Hardy's draft notes recovered for the publication after his death, therefore not necessarily bearing the author's imprimatur.

54 Minakakis (2011: 259). Here the stanza number is 465 . 
The other sources listed in the dictionary-I checked the Skandapurāna $a^{55}$ and Dhanapāla's Tilakamañjarı ${ }^{56}$ _ are again not very revealing.

More references could be added to the Pune headword, but one of the most significant works of Hindu literature, the Moksopay $y$, the older version of the text known as the Yogavassiștha, deserves special mention. This mid 1othcentury philosophical magnum opus too mentions the word and the commentator's gloss is not without interest. ${ }^{57}$

The occurrences taken together seem to suggest that the agniśauca cloth is something rare and precious, worthy of being an expensive gift, that it is white (rarely: yellow) and shiny, that it has an ornamental value, and that as its name shows it is cleansed (gradually) in or by fire without being burned.

\section{Further Buddhist Sources}

While we have breathless admiration for the editors of the Pune Dictionary, in this instance they ignored Buddhist literature completely, although the solution is to be found there.

55 That is to say, the Skandapurāna as known to the Pune lexicographers. Their reference is to the late (17th c.?) Nägarakhanda, the sixth Khanda of the v.s. 1967 (1910 CE) Venkateshvara Steam Press (Bombay) print overseen by Kșemarāja Śrīkṛ̦̣nadāsa. The Revākhaṇda attributed to the Skandapurāna (Giri 1994) has three further equally unrevealing references $(34.36,39.16,63.20)$. I thank Peter Bisschop for correcting an error in a previous version of this note as well as for providing the conjectured date of the Nägarakhanda. The hitherto published portions of the Ur-Skandapurāna (an e-text is available here: https:// www.universiteitleiden.nl/en/research/research-projects/humanities/the-skandapurāna -project\#tab-4) does not contain the word in question.

$5^{6}$ Bhavadatta S'āstrī and Parab (1938). This work was written for the Paramāra king Bhoja who reigned ca. 1000-1055 CE, see Dezső (2012: 74).

57 Krause-Stinner, Krause and Stephan (2019: 106): sādhusañgamaśuddhātmā śāstrārthaparimārjitaḥ | prājño bhāty uddhṛtạ̣ vahner agniśaucam ivāmśukam || 16 || The text of the commentary: śāstreṇa parimārjitạ̣ śuddhīkrtaḥ sạ̣ śāstrārthaparimārjitaḥ | kānicid vastrāṇi kenacid aușadhādinopalipyāgnau kșiptāni santi |nirmalïbhavanti| teșām evāgniśaucakam iti nāma $\|$. The daṇda after santi is surely an error, because we should read this as a neuter plural present participle and not a plural third person indicative. Bhāskarakanțha's note betrays both some familiarity with the matter (awareness of how the cloth is cleansed even adding the element of an additional substance, treating the word as a technical term), but also some uncertainty ('some cloth', 'some kind of medicinal herb etc.'). For the date of the Mokșopāya, see Hanneder (2004: 40-53). For the date of Bhāskarakanthha, late 17th c. rather than the usually held 18th c., see Sanderson (2007: 422). For some of the unique features of the Mokssopāya, see for example Hanneder (2004: 2-4, 90-114). 
One important example, although not the one through which I arrived at the solution, is the *Bhadrapālaśreșthipariprcchā, no. 39 in the Mahāratnakūța [大 寶積經] collection. Here "fire-washed cloth" is mentioned as one of the many types of garments worn by the wives of merchants in Bhadrapāla's splendid retinue. ${ }^{58}$ The Chinese 火浣布 is a perfect semantic cognate of agniśaucavastra, and it is a widely used term for asbestos cloth. The translator, the Gandhäran monk *Jñānagupta [闍那崛多 or 志德], arrived in China around $559 \mathrm{CE}$ and thus flourished in the second half of the 6 th $\mathrm{c}$. This might therefore be the earliest datable and uncontroversial occurrence of the term in India.

Next to the Kārandaryūhasūtra and the *Bhadrapālaśreșthipariprcchā, at least two more sources merit special attention.

The first is Kambala's Álokamālā (ca. 8th c.), a philosophical work, where stanza 98 reads thus: ${ }^{59}$

\section{agniśaucā mrgā vahnim aśnanti vișamūṣikāḥ| vișaiś ca na vipadyante jīvitāntakarair api $\|$}

According to Lindtner's interpretation:60

"Fire-pure" antelopes devour fire, mice [eat] poison-still they are not killed even though these [kinds of] poison are deadly [to other living beings]!

Here once again, as in the Räjataranginī, we have animals, not a cloth, and the animal is termed $m r g a$. The commentary, which survives only in Tibetan translation, adds that these miraculous animals live in a certain country, cleanse themselves in fire, and eat fire. ${ }^{61}$

$5^{8}$ T310, vol. 11, p. 6o8, c, l. 6. The Tibetan (Tōhoku no. 83, 72a) has mes sbyangs pa'i gos as an equivalent. For an English translation of the Tibetan, see Liljenberg and Pagel (2020: section 1.9). The English given here is "garments purified with fire."

59 Lindtner $(1985: 152)$. The text printed by Lindtner is problematic in the second quarter, where he reads vișam mūṣikāh. However, the manuscript (for the time being the only one available, Tōkyō University Library no. 59 / old no. 350, folio 9v) has the metrically correct vișamūṣikăh. This seems to be yet another class of mysterious animals, but this should not concern us now. The term occurs in medical literature (see Meulenbeld 1999-2002), but never as a term for any animal.

6o Lindtner (1985: 153). The rendering "mice [eat] poison" can be dismissed in light of n. 59 just above.

61 Tōhoku no. 3896, 82b-83a: gzhan yang | ri dvags me mdag ces bya ba la sogs pa smos te | yul kha cig na ri dvags me mdag ces bya ba mes dri ma med par'gyur la | gzhan dag ni sreg go | de bzhin du de dag me za'i gzhan dag ni ma yin no ||. This roughly translates as: "Fur- 
The second Buddhist work is the Dharmadhàtustava attributed to Nāgārjuna. Until very recently this text was thought lost in the original, with only very few of the Sanskrit verses surviving in testimonia, including the stanzas we will examine. ${ }^{62}$ Since then a manuscript had been found in China and published by Liu in 2015. My original gateway to the solution, stanzas 20-21 read: 63

\section{agniśaucaṃ yathā vastraṃ malinaṃ vividhair malaị | agnimadhye yathākșiptam malam dagdham na vastratā $\|$ evaṃ prabhāsvaraṃ cittam malinaṃ rāgajair malaị̣| jñānāgninā malaṃ dagdhaṃ na dagdham tat prabhāsvaram \|}

Seyfort Ruegg translated the verse more or less correctly: ${ }^{4}$

Le feu étant pureté, quand un vêtement souillé par des impuretés diverses est placé dans le feu, ce sont les impurités qui sont brûlées et non point le vêtement en soi (vastratā); pareillement le citta lumineaux est souillé par les impuretés de la concupiscence, etc., et c'est l'impureté qui est alors brûlée par le feu de la Gnose (jñāna) et non point ce [citta] qui est lumineux.

However, because he uncritically accepted Carelli's inferior reading agnih śaucam, he begins the translation with an expression ("Le feu étant pureté,") which is difficult to construe with the rest. On the other hand, to the translation he added a remarkably intuitive note: "S' agit-il d' un vêtement fait de fibres d'amiante pouvant être nettoyé par le feu?"

ther, [the author] states [the verse] beginning with agniśaucā mrgāḥ. In a certain country there are beasts called agniśauca, who become free of dirt by fire, whereas other [creatures would] burn [in fire]. In the same way, they also eat fire, whereas other [creatures] do not." The present version may be an erroneous transmission of *mes dag. Normally, me mdag stands for charcoal (ä́gära), cf. Chandra (1993: 1425), Negi (2003: 4479). In what follows, the commentator's text has dug gi byi ba, substantiating the metrically correct but semantically obscure vișamūṣikāh.

62 Carelli (1941: 66), re-edited by Sferra (2006: 188). It is important to note that Carelli's reading is faulty: for agniśaucam it reads agnị̣ śaucam, which affected Seyfort Ruegg's interpretation in 1971, which is cited just below.

63 I used Sferra's edition of the testimony. Liu (2015: 12) has the same as above, save one minor difference: yatha kșiptam. The Tibetan translation of the verses is critically edited on pp. $3^{2-33}$; here we read me yis dag pa'i gos.

64 Seyfort Ruegg (1971: 466). 
The simile of the Dharmadhātustava is also found in late Khotanese (ca. 700-1000 CE), where the name for our cloth is a Sanskrit loanword. ${ }^{65}$

Nāgārjuna is very likely not the author of these verses, so for the dating we must turn to the Chinese translations. ${ }^{66}$ The passage concerning us already occurs in Amoghavajra's [不空金剛] translation (ca. 765 CE), but *Dānapāla's [施護] rendering (ca. 1015-1019 CE) was to me the more revealing one. Amoghavajra's translation already suggests that we are dealing with a fire-cleansed cloth (火洗 [...] 衣), ${ }^{67}$ but *Dānapāla uses a term that was already familiar to Chinese readers for at least six centuries, and which we have seen in the *Bhadrapālaśreșthipariprcchā as well: 火浣布, i.e. asbestos. ${ }^{68}$

The hymn and, by implication, the simile were quite popular with Tibetan authorities. The verses are quoted e.g. in 'Gos Lotsawa Gzhon nu dpal's (1392$1481 \mathrm{CE}$ ) commentary to the Uttaratantra, a noteworthy piece of exegesis studied by Mathes. His translation of the verses figure both in the preface and the main body, ${ }^{69}$ but he does not offer any comments, therefore it can be suspected that the image remained obscure to him.

Somewhat earlier, the Karmapa III Rang byung rdo rje (1284-1339 CE) wrote a commentary on the Dharmadhätustava, a work that has been studied and translated by Brunnhölzl. His translation of the root verses does not evidently lead us to the real import. ${ }^{70}$ However, he seems to be on right track when he renders the commentary thus: ${ }^{71}$

65 Maggi (2007) v. 78 has [...] agnaśauca vāsta [...], with the translation on p. 209 where the reading agnaśauca is corrected to agniśauca on p. 215. But the interpretation is simply 'a fabulous garment'.

66 The attribution too is late. Amoghavajra's translation claims it was written by one *Kșitigarbha, see Liu (2015: xxvi); also see xxviii-xxxii and 66-68 for an earlier Chinese version of questionable authority.

$67 \quad$ T413, vol. 13, p. 79o, b, l. 22; Liu (2015: 49).

68 T1675, vol. 13, p. 754, c, l. 21 and l. 24; Liu (2015: 6o).

69 Mathes (2008: ix, 249): "Like cloth purified by fire, / [That is,] when one puts [a cloth] / Sullied with various stains over a fire, / The stains are burnt but not the cloth, / Similarly, with the luminous mind, / Sullied with stains arisen from desire, / The stains are burnt by wisdom / But not the luminous [mind]." Mathes also gives the Sanskrit (521, n. 1429) with the reading agniśaucam, pointing out that Seyfort Ruegg's reading is different (i.e. that he accepted Carelli's text) and his interpretation ("Le feu étant pureté,") is "syntactically problematic."

70 Brunnhölzl (2007:119): "A garment that was purged by fire / May be soiled by various stains. / When it's put into a blaze again, / The stains are burned, the garment not. / Likewise, mind that is so luminous / Is soiled by stains of craving and so forth. / The afflictions burn in wisdom's fire, / But its luminosity does not." It is evident that he understood tat prabhāsvaram as a compound.

71 Brunnhölzl (2007: 231); bold emphasis of lemmata original. 
[Take a piece of] cotton that was cleansed by fire, or, a garment that is made of asbestos, which then becomes tainted by stains. Through putting it into a blaze, the stains are burned and the garment becomes pure, being as shiny as before. [...]

To this he added the following endnote, ${ }^{72}$ a display of learned intuition, in spite of the fact that he chose the wrong Sanskrit term, as khațikā does indeed mean "chalk":

Skt. khațikā, Tib. rdo rgyus. Monier Williams has "chalk" and Bod rgya tshig mdzod chen mo says "a mineral that, when beaten, becomes like vulture downs." All this matches the features of asbestos, which is a white, fibrous mineral that is fire-resistant and can easily be spun into yarn (see also Webster's International Dictionary, p. 126). RT (p. 633) also has rdo rgyus, Döl (p. 142) has rdo dreg (pitch). ${ }^{73}$

What is furthermore quite remarkable about this note is that here we have two Tibetans in the 14th century glossing the "cloth washed in fire" with two obscure words which must be names of minerals $(r d o)$.

Indeed, there is a slight possibility that 'fire-cleansed' could also have referred to a kind of stone. The passage in question is from the Vajramāla bhidhāna, a long and important scripture of the Guhyasamāja tradition with a history that is not very well understood. The original Sanskrit is lost, but the verse we are interested in is found in quotation in Candrakirti's Pradīpoddyotana (9th c.). ${ }^{74}$ The stanza eulogises a fundamental tantric practice called svādhișthāna: ${ }^{75}$

ratnam anyan na cāstīha svādhișthānād ṛte mahat | prabhāsvaraviśuddhạ̣ ced vahniśuddho maṇir yathā $\|$

Wayman translated this as follows:

\footnotetext{
72 Brunnhölzl (2007: 391, n. 670).

73 Brunnhölzl is referring to RT = Rong ston Śākya rgyal mtshan's (1367-1449 CE) and Döl = Dol po pa Shes rab rgyal mtshan's (1292-1361 CE) commentaries. For the latter, now see Mochizuki 2008, where the gloss is on p. 29.

74 Chakravarti (1984: 17). The verse is 59.41 in the Vajramāläbhidhāna, at least in the numeration of Kittay (2011: 720).

75 The verse is discussed in Wayman (1977:2, 22, 330).
} 
There is no jewel in this world so great as the Svādhișțāna, if purified by the Clear Light like a gem cleansed by fire.

He also notes in his discussion that a commentator, Bhavyakīrti, understood the gem as gold. ${ }^{76}$ The exegete must, it appears, have gold ore in mind. Of course, the semantic range of mani (and for that matter ratna), just like mrga (see below), is much wider than commonly assumed. Gold ore therefore sounds like a perfectly plausible interpretation. However, it could well be the case that Bhavyakīrti II (or the Tibetan translation) is wrong. For asbestos fibre does indeed come from a mineral.

Asbestos (and Fire-Rat or Salamander)

Asbestos is in fact a generic term, as it covers six kinds of silicate minerals. The mineral is processed until fibres are obtained which are then woven. Its use goes back at least 4,500 or 5,000 years, as archaeological evidence shows that inhabitants of Lake Juojärvi region in East Finland used asbestos to strengthen pots and utensils, whereas on Cyprus it was used for the manufacture of i.a. cremation cloths and lamp wicks. ${ }^{77}$ The archaeological evidence for ancient uses is not limited to Europe. Recent finds show its presence ca. 4,000 or 3,500 years ago in Central Thailand, although the question whether it was locally produced or imported has, at least to my knowledge, not been settled yet. ${ }^{78}$ The oldest description we are aware of is from ancient Greece, a lost work of Sotakos of Karystos (ca. end of 4 th c. BCE or later) summarised in Appolonius in the 2nd c. BCE. The English word too is of course Greek in origin ( $\alpha \sigma \beta \varepsilon \sigma \tau о \varsigma$, , "unquenchable" or "inextinguishable"), although this was not the only and not even the oldest designation used for it in the Ancient World..$^{79}$

There is a vast amount of scholarship on this topic, including examinations of its intellectual history, ${ }^{80}$ but this is not the place to even summarise the plot. The study at the heart of the issue as far as Eurasia is concerned is Berthold Laufer's magisterial essay, "Asbestos and Salamander. An Essay in Chinese and

76 Tōhoku no. 1793: 117b-118a of volume KI (the [sub-]commentary stretches across two volumes): [...] mes sbyangs pa'i gser bzhin du [...]. I understand this author to be Bhavyakīrti II, not the Herukābhidhāna exegete Bhavyakīrti I, see Szántó (2012: 43).

77 Ross and Nolan (2003: 449), citing a variety of sources.

78 Cameron (2000). A recent find in Java is discussed in Cameron et al. (2015).

79 Büttner (2004: 24-29).

8o An excellent source is the already mentioned work of Büttner (2004). 
Hellenistic Folk-lore," published in 1915. Hirth (1885:249-252) and Wylie (1897) had already dealt with Chinese material regarding asbestos, and these were pioneering works, but Laufer's overview and analysis is quite simply breathtaking. ${ }^{81}$ Here we can only summarise the most imporant facts.

The Ancient Greek sources show that while people were impressed with the material's qualities, they did not think that asbestos was in any way of supernatural origin, as they were familiar with how it was manufactured. However, this knowledge eventually became lost. As for China, asbestos was originally not produced there, since all early references to it are in the context of tribute brought by embassies from the West. Chroniclers of the Later Han were aware that it was produced in what they called 'Greater Qin' [大秦], that is to say the eastern provinces of the Roman Empire. However, at least since the 4th c., a remarkable connection appears: the Chinese start believing that the material is animal fur. This remarkable beast is referred to as either 'the white rodent' [白鼠] or 'the fire-rat' [火鼠], which was able to withstand fire. The motif was widespread. ${ }^{82}$ Fascinatingly, on the other side of the Eurasian landmass, a similar belief emerges, but here the fur is that of the mythical beast, the salamander.

By the Mongol Period, the Chinese gained (or, as some argue, re-gained) knowledge of the mineral provenance of asbestos. The Great Khan Kublai had a lucrative mine, which is described by Marco Polo. His fascinating account merits more than just a passing mention, so I will quote it in full: 83

The way moreover of making salamanders is this. For I tell you that when one has dug from the mountains some of that vein of which you have heard, and one has torn it and broken it up, it is twisted together and makes threads like wool. And therefore when one has this vein he has

81 Yet more data and analysis is provided in Laufer (1919: 498-501). Also see Needham (1959: $655^{-662)}$.

82 It occurs for example in the Japanese classic fairy-tale, the 1oth-century 'Tale of the Bamboo Cutter.' The heroine, Princess Kaguya, sets tasks to five suitors. Among these, the third has to bring the fur of the legendary fire-rat [火鼠の录] from China. The suitorobliging to the narrative motif of 'the impossible task' - does not obtain the real animal, and his fake is soon revealed by a test of fire. See the text of Taketori Monogatari [个竹取物 語]. Tokyo: Iwanami shoten, 1929, at http://etext.virginia.edu/japanese/taketori/AnoTake .html. For a translation, see Keene (1956).

83 Moule and Pelliot (1938: 156-158). I removed some of the formatting. This is a so-called composite translation of the many and multilingual sources of the Description of the World. The introduction to the passage mentions that Marco Polo did not witness the process himself, but relied on the account of one Çulfikar (i.e. D̄ū-'l-faqār), a Turk merchant, whom he deemed 'very knowing and [...] trustworthy' Also see Pelliot (1959-1973: 1.611), Büttner (2004: 58-6o) and Vogel (2013: 62-63). 
it dried in the sun; and then when it is dry he has it pounded in a great copper mortar; and then when it is pounded he has it washed with water, and only that thread like wool of which I have told you stays on the top of the water, and all the earth clinging there, which is worthless, falls off, goes to the bottom of the water, \& is thrown away. Then this thread which is like wool, he has it well spun like wool and then he has it woven \& cloth or towels \& mantles made of it, which we say are of salamander. And when the towels are made I tell you that they are not at all quite white, and they are brown when they are taken from the loom. But when they wish to make them white they put them in the fire and leave them to stay there a space of an hour, and when it is taken out the towel becomes very white like snow. And whenever these salamander towels have any soil or stain one puts them in fire and leaves them there a space and they are not burnt up nor hurt but become white like snow; \& in that way they keep them pure \& clean. And this is the truth of the making of the salamander which I have told you, no other. I have seen it with my eyes put into the fire \& come back very white. And those of the country tell it in this way themselves, but of the salamander serpent which is said to live in the fire I heard nothing in the parts of the east; and all the other things which are said of it, that it is an animal, are lies and fables. And again I tell you that there is a towel of it at Rome which the great Kaan sent to the Apostle for a very great present when he sent him the two brothers for ambassadors, and for this reason the holy napkin of our Lord Master Jesus Christ (may he be blest!) was put inside it, and on this towel were written in letter of gold these words, Tu es Petrus et super hanc petram edificabo ecclesiam meam.

While this is a perfectly genuine description, contemporaries and their descendants were not impressed and probably simply put it down as yet another of Il Milione's lies and fables. ${ }^{84}$ The belief that asbestos is salamander fur held out stubbornly into the Early Modern period.

84 Shockingly, the controversy over the genuineness of Marco Polo's travels is still raging, see Wood (1996). The latest scholarly rebuttal of Wood's thesis is Vogel (2013, of which a good review with thoughtful comments is Atwood 2015). See Vogel (2013:5) on early sceptics. 
In my view the Indic evidence is a piece of the same puzzle. Based on the descriptions of its properties and the Buddhist Sanskrit translations into Chinese, the agniśauca cloth can hardly be anything but asbestos. The puzzling fact that the word agniśauca refers to animals too is now clear in light of the evidence we have from outside India: the mrga so termed is essentially the Indian sibling of the Chinese fire-rat/white rodent and the European/Middle Eastern salamander. ${ }^{85}$

While there is no clear evidence from India that learned authors saw a connection between the two, they must have done so, otherwise it is difficult to explain why the same term, agniśauca, is used for both.

As for how Kambala's and others' mrga appears as a deer or antelope in Kalhana, I can only cite the doyen of South Asia epigraphy, D.C. Sircar, who in the introduction to his Aśokan Studies writes:86

The next difficulty was that the Hindi Division of the Ministry [of Information and Broadcasting] noticed some out of the many differences between my interpretation of the edicts and their Hindi translation prepared by another gentleman, and I was invited to a meeting at Professor Radhakrishnan's residence to meet the Hindi translator and a few officers. There, at the outset, I drew the Professor's attention to only one of the points raised, in which my translation of the word $m r g a$ as 'an animal' was regarded as wrong and the meaning 'a deer' adopted by the Hindi translator was stated to be correct. Professor Radhakrishnan at once observed that mrga is generally 'an animal' and particularly 'a deer' whereupon the Secretary of the I. and B. Ministry pointed out that the context appears to

85 The cloth and the salamander also figure in Arabic literature. A few examples should suffice. In Sykes (1915: 486-487), a napkin thrown into the fire for it to be cleaned is listed by al-Tabarī (839-923 CE) among the miraculous riches of Khusrow II. In King (2017: 57-58) we are told that Arabs talked of al-samandal as a bird, sometimes confusing it with the phoenix, or a small mammal, and that an item made from samandal "bird-skin" was sent by the Pāla emperor Dharmapāla to the caliph al-Ma'mūn. On this, see below. See Levey (1966: $5^{6-58)}$ for the magical properties of the salamander described in a toxicological treatise from the mid-1oth c. CE, using Indian materials. We also see the salamander as a motif in Ottoman poetry (Andrews and Kalpaklı 2005: 96-97). The salamander is present even in Rabbinical exegesis, see Reuven Chaim Klein's "Salamandra and the Flames of Hell," an unpublished and undated draft essay here: https://www.academia.edu/116o22o/ Salamandra_and_the_Flames_of_Hell (last accessed on May 16, 2020). 
support the second meaning. I politely replied that it was possible for me only to follow my own ideas and not the opinion of the officer.

The semantic range of $m r g a$ is indeed large, sometimes encompassing even elephants, ${ }^{87}$ but at least to my knowledge never predatory felines (note that the lion is termed their lord, mrgapati). It would seem that $m r g a$ can denote a large class of undomesticated animals. Naturally, mrga does indeed often mean deer or antelope, which probably explains Kalhaṇa's usage.

This could suggest that Indians at some point were aware of the concept that the asbestos cloth is the fur of some kind of animal such as the salamander or a rodent, and chose to name it by the most generic apposite term in Sanskrit, mrga.

If we look back at the passages I have dealt with in this paper and understand 'asbestos' for the agniśauca cloth everywhere, the images suddenly start making perfect sense. Because of its high resistance to temperature, asbestos cloth can indeed be cleaned in fire, because the impurities soiling it will burn away leaving the cloth intact.

Thus, Kādambari is burned by the fire of love, but that makes her even more beautiful. Because of this property, it is perfectly natural to assume some kind of connection with the fire-god, hence it is apposite that it is Agni's gift in the Mārkandeyapurāna and elsewhere. It now makes perfect sense that Kārkoțaka's gift in the Kathāsaritsāgara was asbestos, because he was taken away from near a fire. Penzer's suspicion that this was somehow related to the salamander in Prester John's account is now proven, as is Seyfort Ruegg and Brunnhölzl's intuition for the image in the Dharmadhätustava. Govardhana's image too makes perfect sense. To turn the simile around: asbestos must have been quite rare, just as that love which can withstand the fire that it will find in the mouths of rogues. Thus, because it was rare, it was precious and therefore suitable as a fine gift or to be imagined as worn as a splendid garment.

The fundamental problem of where and when exactly the idea of asbestos being animal fur emerged cannot be solved at present. However, the fact remains that it held out over a vast amount of geographical space and historical time. The present paper would have remained content with merely adding India to the story of this remarkable cultural curiosity.

However, we can also discuss the hypothesis that asbestos manufacturing continued at least in some parts of mediaeval India and that therefore the

87 Haraprasad Shastri (1919: 307-309). 
image of the agniśauca was not just poetic convention but common knowledge. There is very good evidence that between ca. 800 and 1100 CE, the Pāla Empire did possess the knowledge of asbestos manufacturing.

In the Arabic Book of Gifts and Rarities we see a copy of a letter sent by themore likely: $a$ - king of India, Dahmī, to the seventh Abbasid caliph, al-Ma'mūn $(r .813-833 \mathrm{CE}) .{ }^{88}$ Accompanying this letter was a series of gifts, including "three small rugs (mușallayāt) [with] their cushions (wasāìd) stuffed with the feathers of a bird called samandal, which, when thrown into fire, do not burn." Some authorities identify Dahmī with the Pāla emperor, Dharmapāla. ${ }^{89}$ However, in an account hailing from the middle of the 9 th $\mathrm{c}$. and another from later, one of the realms of India is still referred to as Dharma..$^{90}$ By this time Dharmapāla's reign was over by at least four decades, and indeed, as most Pāla historians believe, it probably ended even before $810 \mathrm{CE},{ }^{91}$ earlier than the caliph's assuming the throne. It could be that Dahmì and related words were generic Arab terms for the Pāla Empire, regardless of who the emperor was. For the period coinciding with al-Ma'mūn's reign the most likely candidate is Dharmapāla's very successful son, Devapāla. As for the gift, we can see that there were at least three cushions to match the three rugs. This suggests something not of unique rarity. In other words, the material, though rare and precious, was available in larger quantities. (Note that the near contemporary Păla court poet, Abhinanda, imagined many tents made of the stuff.) This suggests accessibility to manufacture somewhere in the Pāla heartland or a conquered territory.

There is incontrovertible evidence from the first half of the 11th c. that at least some people in South Asia (most likely in the Pāla realms) were aware that asbestos came from a stone and thus probably knew how it was produced.

88 Qaddūmī (1996: 73-75).

89 King (2017: 57-58), perhaps following Qaddūmī.

90 Maqbul Ahmad (1989: 9-12, 43-44), but also Sauvaget (1948:13-14, 52-53). Other kingdoms are named similarly: al-Jurz are the Gurjaras, Balharā are the Vallabhas (from Vallabharāya, i.e. the Rāștrakūțas). Some variants include a different spelling, with $r$ (i.e. Rahmī). If a scribe of Arabic is not familiar with a foreign word, $d$ can very easily become corrupted to $r$. Other details too match the Pālas, e.g. their military conflict with the Gurjaras and the Rāștrakūțas (the so-called tripartite struggle for the control of Kanauj) or their extensive use of war elephants. The letter sent to the caliph mentions a large Buddha statue, and the Pālas (styling themselves paramasaugata in their inscriptions) were major patrons of Buddhism.

91 Bhattacharya (1988: 71). It should be noted that early Pāla chronology still poses difficult problems. 
This piece of evidence is a passage in the Vimalaprabhā of Pundiarīka, a commentary on the Laghukālacakratantra. ${ }^{92}$ The äryā verse reads thus: ${ }^{93}$

\author{
dagdhaṃ śikhinaiva śilā- \\ valkalasūtrāṃśukaṃ bhavati śuddham | \\ yadvat tadvat pumsā̄m \\ prajñājñ̄ānena saccittam \|
}

Newman's translation of the verse: ${ }^{94}$

Cloth of asbestos thread is purified just by burning it in fire. Likewise, the noble mind of men is purified by wisdom-gnosis.

The term śilāvalkalasūtrāṃśukam ('cloth [made of] stone-bark-thread') is noteworthy, because it shows knowledge that the fibre is of mineral origin. A completely unstudied anonymous sub-commentary/vademecum, which is available only in Tibetan, adds: 95

As for śilâvalkala, there is a certain stone, which if split down the middle (or: stained/defiled) and burned, becomes free of impurities.

92 For the early history of this tradition, see Sferra $(2005,2015)$. As for the date of the Vimalaprabhā, Newman (1998) argues that the tantra and the commentary were completed by ca. 1025-1040 CE. Sferra reasonably prefers a slightly earlier date and points out several phases of development. The exact area where the Kālacakra system emerged is unclear, but I think that the Pāla Empire is a very likely candidate.

93 Upadhyaya (1986: 6). The edition's typesetting, prompted by a corruption in the previous verse, is confusing here.

94 Newman $(1987: 232)$. There are no notes to this remarkable image (and remarkably correct translation). Prof. Newman informs me that it was an educated guess informed by the context and the Monier-Williams reference to medical literature (personal communication, e-mail May 19, 2020). The Tibetan (Tōhoku no. 845, 4b \& Tōhoku no. 1347, 110a) has rdo dreg skud pa'i gos, using a term we already saw.

95 Tōhoku no. 1349, 52a: rdo dreg ni rdo 'ga' zhig gi dbus su bags par 'gyur ba bsregs par gyur pas dri ma med par 'gyur ro $\|$. Shortly after this passage, the way the cloth is purified is also described: if soiled, it is smeared with butter and thrown into a big fire (rdo dreg gis skud pa'i gos dri ma can ni mar gyis byugs pa me chen po la thal bar byas pa dri ma med pa nyid du nye bar' 'gro ba ji lta ba [...]). For substances being applied to the cloth before it is placed into fire, see here n. 57 . The translation dates from the first half of the 14th $\mathrm{c}$. as the translator was Dpang lo Blo gros brtan pa (1276-1342 CE). The sub-commentary *Padmini (Tōhoku no. 1350, 95a: dper na rdo dreg gi skud pas byas pa'i gos ni me yi nang du bcug na me yis dag par byed kyi tshig par mi byed pa ji lta ba [...]) mentions only the way the cloth is purified in fire. 
This is accurate knowledge about the asbestos mineral and its turning into fireproof cloth.

However, apparently this knowledge was forgotten in India, too, albeit later than elsewhere. Post-mediaeval authors, with the exception of Bhāskarakantha (see n. 57), do not display clear knowledge about the term; moreover, the literature which ought to talk about asbestos, rasaśāstra, is, as far as I can tell, silent. The only term we can find here is kauśeyāśman ('silk-stone'), very likely a neologism, as it appears only in modern works. ${ }^{96}$

For the sake of convenience, here is a timeline of the most important datable Indic attestations of agniśauca and synonyms in the mediaeval period:

1. The Kärandaryūhasütra (late 4th or early 5 th c.?) can be suspected to have contained the term agniśaucavastra as a gift item.

2. *Jñānagupta (523-60o CE), after 559 CE, the date of his arrival in China, translates an unknown Sanskrit word (most likely *agniśaucavastra) meaning a splendid garment in the *Bhadrapālaśreșthipariprcchā with 火 浣布, already a standard name for asbestos.

3. Bhūṣanabhațta's continuation to his father's Kädambarī (second half of the $7^{\text {th }} \mathrm{c}$.) likens the heroine's beauty burned by the fire of love to agniśaucam amśukam.

4. The Dharmadhātustava (early 8th. c.?) likens the mind burned by gnosis to the agniśaucam vastram. Ca. $765 \mathrm{CE}$, Amoghavajra translates this as 火 洗 $[\ldots]$ 衣.

5. The same image is used in the late Khotanese Book of Vimalakirti (ca. 700$1000 \mathrm{CE}$ ). The term is a Sanskrit loanword.

6. Kambala's Ālokamāalā (ca. 8th c.) mentions agniśaucā mrgāḥ who eat fire without being hurt.

7. The Mārkandeyapurāṇa's Durgāsaptaśatī/Devīmāhātmya (ca. 8th c.) mentions agniśauce vāsasī as a gift by the fire-god.

8. Sometime between $813-833 \mathrm{CE}$, a Pāla emperor sends a gift containing asbestos to the seventh Abbasid caliph.

9. One generation later, the mid-gth-c. Pāla court poet Abhinanda mentions maṇdapas made of agniśaucāmśuka in his Rāmacarita.

10. Candrakīrti (ca. gth c.) quotes the Vajramäläbhidhāna, which has vahniśuddho manih, more likely gold ore than asbestos mineral.

11. Ratnākara's Haravijaya (second half of the gth c.) mentions agniśauca and agniśaucam vasanam in poetic images of purity.

96 Meulenbeld (1999-2002: IIA, 640, 654). 
12. Rājaśekhara's Bālarāmāyaṇa (early 1oth c.) has agniśaucāméukāni, same as above.

13. Trivikramabhațța's Nalacampū (early 1oth c.) has analaśaucam cināmenśukapatțaparidhānayugalam as a gift.

14. The anonymous Kashmirian Mokșopayya (middle of the 1oth c.) uses the purification of the agniśauca cloth as a simile for a learned man.

15. *Dānapāla (ca. 1015-1019 CE) translated the occurrence in the Dharmadhätustava with the standard Chinese 火浣布.

16. Dhanapāla's Tilakamañjarì (early 11th c.) uses agniśaucasicaya as an image of purity.

17. Puṇarīka's Vimalaprabhā (early nth c.) calls the cloth śilāvalkalasūtrāṃśukam, showing awareness that the fibre is of mineral provenance.

18. Somadeva's Kathāsaritsāgara (second half of the 11th c.) has agniśaucākhyam vastrayugam and agniśaucam vastrayugalam as a gift to Nala by Kārkoțaka. The first perhaps suggests usage as a technical term.

19. Divākaracandra (ca. second half of the 11th c.) uses agniśaucavastra in a nyāya expression in a tantric Buddhist ritual manual.

20. Kalhaṇa's Rājatarañgin̄i (1148-1149 CE) mentions antelopes cleansing in fire thrice: harị̣i hutāśaśaucā, agniśauceṇakānām, and agniśaucaḥ sārañgah.

21. Alaka (ca. 12th c.) glosses Ratnākara perhaps suggesting that it is a technical term: agniśaucam nāma sicayam.

22. Hemacandra (1088-1172 CE) uses the image of agniśaucam amśukam / agniśaucāmśukam as a simile for the Jain meditator's gradual purification through the 'fire' of meditation.

23. Govardhana's Āryāsaptaśatī (ca. 1200 CE) uses analaśaucam aṃśukam in a simile about rare love.

24. The Jaina recension of the Simhāsanadvātrimśika (later than the 13th c.) has vahnidhauta cloth as a gift accompanying a throne.

\section{Acknowledgments}

I owe thanks to a great number of generous people: the two anonymous peer reviewers, Anne Bancroft, Csaba Dezső, Ryosuke Furui, Alastair Gornall, Arlo Griffiths, Jens-Uwe Hartmann, Harunaga Isaacson, Berthe Jansen, Chris Jones, Anett Krause, Kenichi Kuranishi, Julia Lawless, Corinna Lhoir, Philipp Maas, Noel Malcolm, James Mallinson, Ádám Mestyán, Dolores Minakakis, Arik Moran, John Newman, Miklós Sárközy, Jonathan Silk, Christophe Vielle, Klaus Wille, and $†$ Stefano Zacchetti. Some of the research was conducted in Oxford; 
I owe thanks to the Warden and Fellows of All Souls College. This paper is a significantly expanded and improved version of an article originally written in Hungarian (Szántó 2015b). This work was supported by the European Research Council (ERC) under the Horizon 2020 program (Advanced Grant agreement No. 741884$)$.

\section{Note}

What I mean by 'India' in this paper is Sanskrit-writing Northern South Asia, a shared space of 'Hinduism', Buddhism, Jainism, and many other communities. Regretfully, I am ignorant of matters relating to the South and I expect valuable observations from colleagues who are experts in those fields. I refer to periods such as Early Modern purely as a matter of convenience; I am not suggesting that these can be successfully applied to India.

\section{References}

Andrews, Walter G. and Mehmet Kalpakl. 2005. The Age of Beloveds: Love and the Beloved in Early Modern Ottoman and European Culture and Society. Durham NC: Duke University Press.

Apte, Vaman Shivaram. 1957. A Practical Sanskrit-English Dictionary. Revised and Enlarged Edition. Poona: Prasad Prakashan.

Atwood, Christopher. 2015. Review of Vogel 2013. Inner Asia 17: 351-357.

Banerjea, K.M. (ed.) 1865. The Nárada Pancha Rátra. Bibliotheca Indica. Calcutta: Bishop's College Press.

Baring-Gould, Sabine. 1867. Curious Myths of the Middle Ages. Second edition, revised and enlarged. London, Oxford, and Cambridge: Rivingtons \& New York: George Routledge and Sons.

Bhandarkar, D.R. 1907-1908. “Two Grants of Indraraja III.; Saka-samvat 836." Epigraphia Indica 9: 24-41.

Bhattacharya, Gouriswar. 1988. "The New Pāla Ruler Mahendrapāla: Discovery of a Valuable Charter." South Asian Studies 4: 71-73.

Bhaț̣āāāya, Taranatha Tarkavachaspati. 1873. Vācaspatya: brhat saṃskrtābhidhāna/ Vachaspatya: A Comprehensive Sanscrit Dictionary. Calcutta: Kavya Prakasha Press.

Bhavadatta S'āstrī, Paṇdit and Kās'īnāth Pānụurang Parab (eds.). 1938. The Tilaka=Mañjarī of Dhanapāla. Kāvyamālā 85. Bombay: 'Nirṇaya Sāgar' Press.

Bollée, Willem. 2015. A Cultural Encyclopaedia of the Kathāsaritsāgara in Keywords: Complementary to Norman Penzer's General Index on Charles Tawney's Translation. 
Studia Indologica Universitatis Halensis 8. Halle an der Saale: Universitätsverlag Halle-Wittenberg.

Böhtlingk, Otto and Rudolph Roth. 1871. Sanskrit-Wörterbuch, sechster Theil. St. Petersburg: Kaiserliche Akademie der Wissenschaften.

Böhtlingk, Otto. 1886. Sanskrit-Wörterbuch in kürzerer Fassung, sechster Theil. St. Petersburg: Kaiserliche Akademie der Wissenschaften.

Brunnhölzl, Karl. 2007. In Praise of Dharmadhātu by Nāgārjuna. Commentary by the IIIrd Karmapa. Nitartha Institute Series. Ithaca NY: Snow Lion Publications.

Bühler, Georg. 1889. Ueber das Leben des Jaina Mönches Hemachandra, des Schülers des Devachandra aus der Vajraśâkhâ. Wien: F. Tempsky.

Büttner, Jan Ulrich. 2004. Asbest in der Vormoderne. Vom Mythos zur Wissenschaft. Cottbuser Studies zur Geschichte von Technik, Arbeit und Umwelt Band 24. Münster: Waxmann Verlag.

Cameron, Judith. 200o. "Asbestos Cloth and Elites in Southeast Asia." Indo-Pacific Prehistory Association Bulletin 19 (Melaka Papers, Volume 3): 47-51.

Cameron, Judith, Agustijanto Indrajaya and Pierre-Yves Manguin. 2015. "Asbestos textiles from Batujaya (West Java, Indonesia): Further evidence for early long-distance interaction between the Roman Orient, Southern Asia and island Southeast Asia." Bulletin de l'École française d'Extrême-Orient 101: 159-176.

Carelli, Mario. E. 1941. Sekoddeśațīkā of Naḍapāda (Nāropā) Being a commentary of the Sekoddeśa Section of the Kālacakra Tantra. Gaekwad's Oriental Series XC. Baroda: Oriental Institute.

Chakravarti, Chintaharan (ed.). 1984. Guhyasamājatantrapradīpodyotanațīkā-șațkoțīvyākhyā. Tibetan Sanskrit Works Series No. 25. Patna: Kashi Prasad Jayaswal Research Institute.

Chandra, Lokesh. 1993. Tibetan Sanskrit Dictionary, Supplementary Volume 5. Śatapițaka Series Volume 375. New Delhi: International Academy of Indian Culture \& Aditya Prakashan.

Coburn, Thomas B. 1991. Encountering the Goddess. A Translation of the Devī-Māhātmya and a Study of Its Interpretations. SUnY Series in Hindu Studies. Albany: State University of New York Press.

Dezső, Csaba. 2012. "The Story of the Irascible Yakșa and the King Who Nearly Beheaded Himself in Dhanapāla's Tilakamañjarī. Studies in Fabulous Creatures II." Journal of the Royal Asiatic Society Series 3, 22/1: 73-91.

Doshi, Saryu and Moti Chandra. 1980. "Costumes Through the Ages-Notes." Mārg 33/1: 19-59.

Durgâprasâd, Pandit, and Kâsînâth Pândurang Parab (eds.). 189o. The Haravijaya of Râjânaka Ratnâkara. With the Commentary of Râjânaka Alaka. Kâvyamâlâ 22. Bombay: Nirṇaya-sâgara Press.

Durgâprasâd, Pandit, Kâśinâth Pândurang Parab, and Wâsudev Laxmạ̣ Shâsti Pạ̣- 
sikar (eds.). 1915. The Kathâsaritsâgara of Somadevabhatta. Third edition. Bombay: Nirnaya-sagar Press.

Durgāprāsad, Pạ̣ḍit, Kās'ināth Pāṇụurang Parab, and Vāsudev Laxmaṇ S’āstrī Paṇs'îkar (eds.). 1934. The Āryā-saptas'atī of Govardhanāchārya with The Commentary Vyañgyārtha-dīpanā of Anañta-paṇịt. Third Revised Edition. Kāvyamālā 1. Bombay: Nirṇaya Sāgar Press.

Edgerton, Franklin. 1926. Vikrama's Adventures or The Thirty-two Tales of the Throne. A collection of stories about King Vikrama, as told by the thirty-two statuettes that supported his throne. Edited in four different recensions of the Sanskrit original (Vikramacharita or Sinhasana-dvatrinçaka) and translated into English with and introduction. Part 1: Translation, in Four Parallel Recensions. Harvard Oriental Series 26. Cambridge MA: Harvard University Press.

Farquhar, J.N. 1920. An Outline of the Religious Literature of India. London: Oxford University Press.

Farquhar, J.N. 1926. "Review of: The Narada Pancharatra." Journal of the Royal Asiatic Society of Great Britain and Ireland 3: 492-495.

Fynes, R.C.C. (trans.). 1998. Hemacandra. The Lives of the Jain Elders. Oxford World's Classics. Oxford: Oxford University Press.

Ghatage, M. (ed.). 1977. An Encyclopaedic Dictionary of Sanskrit on Historical Principles. Volume I. Part 2. Poona: Deccan College Postgraduate and Research Institute.

Giri, On̉kārānanda (ed.). 1994. Bṛhat-śrīnarmadāpurāṇam revākhaṇdam (parivardhita tritīya saṃskaraṇa). Hośañgābāda: Jñānasatra Prakāśana Nyāsa.

Govinda Deva Śástri, Pandit (ed.). 1869. The Bálarámáyana. A Drama by Rájaśekhara. Benares: Medical Hall Press.

Hanneder, Jürgen. 2004. "Studies on the Mokṣopāya." Habilitationsschrift, Universität Hamburg.

Haraprasad Shastri, Mahamahopadhyaya. 1919. "I.-Contributions of Bengal to Hindu Civilization." The Journal of the Bihar and Orissa Research Society 5/3: 307-324.

Hardy, Friedhelm (trans.) 2009. Seven Hundred Elegant Verses by Govardhana. The Clay Sanskrit Library 55. New York: New York University Press \& JJC Foundation.

Hinüber, Oskar von. 2014. "The Gilgit Manuscripts. An Ancient Buddhist Library in Modern Research." In: Paul Harrison and Jens-Uwe Hartmann (eds.), From Birch Bark to Digital Data: Recent Advances in Buddhist Manuscript Research. Papers Presented at the Conference Indic Buddhist Manuscripts: The State of the Field. Stanford, June 15-19 2009. Österreichische Akademie der Wissenschaften, PhilosophischHistorische Klasse Denkschriften, 46o. Band. Wien: Verlag der Österreichischen Akademie der Wissenschaften, pp. 79-135.

Hirth, Friedrich. 1885. China and the Roman Orient: Researches into Their Ancient and Mediceval Relations as Represented in Old Chinese Records. Leipsic \& Munich: Georg Hirth / Shanghai \& Hongkong: Kelly \& Walsh. 
Jacobi, Hermann (ed.). 1891. Sthavirâvalî Charita or Pariśishțaparvan Being an Appendix of the Trishashțiśalâkâ Purusha Charita by Hemacandra. Calcutta: Asiatic Society.

Jacobi, Hermann (ed.). 1932. Sthavirāvalīcarita or Pariśișțaparvan Being an Appendix of the Trișaști-śalākāpuruṣacarita by Hemacandra. Second edition. Calcutta: Asiatic Society.

Jaini, Padmanabh S. (ed.). 1979. Sāratamā. A Pañjikā on the Așțasāhasrikā Prajñāpāramitā Sūtra By Ācārya Ratnākaraśānti. Tibetan Sanskrit Works Series No. XVIII. Patna: Kashi Prasad Jayaswal Research Institute.

Johnson, Helen M. (trans.). 1931. Trișașțiśalākāpurușacaritra Vol. I Ādīsvaracaritra Translated into English. Gaekwad's Oriental Series No. LI. Baroda: Oriental Institute. Joshi, S.D. (ed.). 1991. An Encyclopaedic Dictionary of Sanskrit on Historical Principles. Volume Four. Part Two. Poona: Deccan College Postgraduate and Research Institute.

Kane, P.V. (ed.). 1913. Kâdambarî (Uttarabhāga). Edited with an Introduction, Notes and Appendices. Bombay: privately published.

Keene, Donald (trans.). 1956. "The Tale of the Bamboo Cutter." Monumenta Nipponica 11/4: 329-355.

King, Anya H. 2017. Scent from the Garden of Paradise: Musk and the Medieval Islamic World. Leiden: Brill.

Kittay, David R. 2011. "Interpreting the Vajra Rosary: Truth and Method Meets Wisdom and Method." PhD dissertation, Columbia University.

Krause-Stinner, Susanne, Anett Krause and Peter Stephan (eds.). 2019. Mokșopāya. Das Sechste Buch. Nirvānaprakaraña. 2. Teil: Kapitel 120-252. Anonymus Casmiriensis: Mokṣopāya. Historisch-kritische Gesamtausgabe. Herausgegeben unter der Leitung von Walter Slaje. Textedition. Teil 6. Akademie der Wissenschaften und der Literatur, Mainz. Veröffentlichungen der Fächergruppenkommission für Außereuropäische Sprachen und Kulturen. Studien zur Indologie. Wiesbaden: Harrassowitz.

Laufer, Berthold. 1915. "Asbestos and Salamander. An Essay in Chinese and Hellenistic Folk-lore." T'oung Pao, Second Series 16/3: 299-373.

Laufer, Berthold. 1919. Sino-Iranica. Chinese Contributions to the History of Civilization in Ancient Iran With Special Reference to the History of Cultivated Plants and Products. Anthropological Series Vol. Xv, No. 3. Chicago: Field Museum of Natural History.

Layne, Gwendolyn (trans.). 1991. Bāṇabhațta. Kādambarī, A Classic Story of Magical Transformations. New York \& London: Garland Publishing.

Liljenberg, Karen and Ulrich Pagel (trans.). 2020. The Questions of Bhadrapāla the Merchant. 8400o: Translating the Words of the Buddha. https://read.8400o.co/translatio n/toh83.html (last accessed on May 16, 2020).

Lindtner, Christian. 1985. "A Treatise on Buddhist Idealism: Kambala's Ālokamālā." In Lindtner, Christian (ed.): Miscellanea Buddhica. Indiske Studier v. Copenhagen: Akademisk Forlag, pp. 109-221. 
Liu, Zhen [刘震]. 2015. The Dharmadhātustava. A Critical Edition of the Sanskrit Text with the Tibetan and Chinese Translations, a Diplomatic Transliteration of the Manuscript and Notes. Sanskrit texts from the Tibetan Autonomous Region, No. 17. Beijing/Vienna: China Tibetology Publishing House/Austrian Academy of Sciences Press.

Levey, Martin. 1966. "Medieval Arabic Toxicology: The Book on Poisons of Ibn Waḥshìya and Its Relation to Early Indian and Greek Texts." Transactions of the American Philosophical Society 56/7: 1-130.

Maggi, Mauro. 2007. "Vimalakīrtinirdeśasūtra Quotations in the Khotanese Book of Vimalakīrti." In Macuch, M., Mauro Maggi and W. Sundermann (eds.), Iranian Languages and Texts from Iran and Turan. Roland E. EmmerickMemorial Volume. Iranica 13. Wiesbaden: Harrasowitz Verlag, pp. 205-223.

Mahādēva Śāstrī, K.S. (ed.). 1953. Mālatīmādhava of Bhavabhūti with the Commentary Rasamañjarī of Pürnasarasvatī. Trivandrum Sanskrit Series No. 170. Trivandrum: Government Central Press.

Mani, Vettam. 1975. Purānic Encyclopaedia. A Comprehensive Dictionary with Special Reference to the Epic and Purānic Literature. Delhi: Motilal Banarsidass.

Maqbul Ahmad, S. 1989. Arabic Classical Accounts of India and China. Book One: AlMasālik wa'l-Mamālik, Roads and Kingdoms by Ibn Khurdādhbih d.c. A.H. 300/A.D. 912. Book Two: Akhbār al-Șin wa'-Hind, An Account of China and India by Sulaymān al-Täjir et al. Compiled in A.D. 851. Translated from Original Arabic with Commentaries. Shimla: Indian Institute of Advanced Studies in association with Calcutta: RddhiIndia.

Marāṭhe, Vāsudevaśāstrī and Puruṣottamaśāstrī Rānaḍe (eds.). 1935. Brahmavaivartapurāṇam, vol. 2. Ānandāśramasaṃskṛtagranthāvaliḥ 102. Punyākhyapattana [Pune]: Vināyak Gaṇeś Āpțe.

Mathes, Klaus Dieter. 2008. A Direct Path to the Buddha Within. Gö Lotsāwa's Mahāmudrā Interpretation of the Ratnagotravibhāga. Studies in Indian and Tibetan Buddhism. Somerville MA: Wisdom Publications.

McCrea, Lawrence. 2014. "The Poetics of Perspective in Rājaśekhara's Young Rāmāyaṇa." In Yigal Bronner, David Shulman, and Gary Tubb (eds.), Innovations and Turning Points: Toward a History of Kārya Literature. Oxford: Oxford University Press, pp. 415-442.

Minakakis, Dolores. 2001. "Upanișads of the Non-Dualism of Love: Govardhana's Āryāsaptaśatī." PhD dissertation, University of Hamburg.

Misra, Pandit Keshi (ed.). 1931. The Aryasaptasati of Govardhanacharya with the Commentary (Rasapradipika) of Maithil Shrotriya Mahamahopadhyaya Pandit Sachal Misra (Otherwise known as Bhabaninath). Darbhanga: Rāj Press and Laheriyāsarāy: Vidyāpati Press.

Miśra, Rām Chandra (ed.). 1973. Kādambarī (Uttarārdha) of Son of Bāṇabhatța Edited 
With The Chandrakalā and Vidyotinī Sanskrit Hindi Commentaries, Notes, Introduction, Etc. The Kashi Sanskrit Series 151. Varanasi: Chowkhamba Sanskrit Series.

Mette, Adelheid. 1997. Die Gilgitfragmente des Kāraṇdaryūha. Monographien zu den Sprachen und Literaturen des indo-tibetischen Kulturraumes Band 29. SwisttalOdendorf: Indica et Tibetica Verlag.

Mette, Adelheid and Ruriko Sakuma. 2017. "Introduction: Kāraṇdaryūha." In: Adelheid Mette, Noriyuki Kudo, Ruriko Sakuma, Chanwit Tudkeao, and Jiro Hirabayashi (eds.), Further Mahāyānasūtras. Gilgit Manuscripts in the National Archives of India, Facsimile Edition Volume II.4. New Delhi: The National Archives of India and Tokyo: The International Research Institute for Advanced Buddhology, Soka University, pp. xix-xxxiv and plates on p. 109.

Meulenbeld, Jan G. 1999-2002. A History of Indian Medical Literature. 3 vols. Groningen Oriental Studies Volume XV. Groningen: Egbert Forsten.

Mochizuki, Kaie. 2008. "On the Commentary to the Dharmadhātustava by Dol po pa (II)." Acta Tibetica et Buddhica 1: 17-44.

Monier-Williams, Monier. 1899. A Sanskrit-English Dictionary Etymologically and Philologically Arranged with Special Reference to Cognate Indo-European Languages. New Edition, Greatly Enlarged and Improved (with the collaboration of E. Leumann and C. Cappeller). Oxford: The Clarendon Press.

Moule Arthur Cristopher and Paul Pelliot. 1938. Marco Polo. The Description of the World. Volume I. London: George Routledge \& Sons.

Negi, J.S. 2003. Bod skad dang legs sbyar gyi tshig mdzod chen mo [pod bcu ma $\mid$ ma |] Tibetan-Sanskrit Dictionary [vol. 10]. Sarnath: Central Institute of Higher Tibetan Studies.

Needham, Joseph. 1959. Science and Civilisation in China. Volume 3: Mathematics and the Sciences of the Heavens and the Earth. Cambridge: Cambridge University Press.

Newman, John. 1987. "The outer Wheel of Time: Vajrayāna Buddhist cosmology in the Kālacakra tantra." PhD dissertation, University of Wisconsin, Madison.

Newman, John. 1998. "The Epoch of the Kālacakra Tantra." Indo-Iranian Journal 41: 319349 .

Parab, Kās'īnâth Pānḍurang (ed.). 1948. The Kādambarī of Bānaabhaț̣a and His Son (Bhușanabhațta) with the Commentaries of Bhānuchandra and His Disciple Siddhachandra (Proteges of the Emperor Akbar), Ninth Edition Revised with His Own Commentary Named Chașaka by Mathurānāth S'āstrī, Professor, Maharaja Sanskrit College, Jaipur. Bombay: Satyabhāmābāī Pāṇḍurañg for the 'Niraṇya-Sāgar' Press.

Parab, Kâs'înâth Pândurang and Wâsudeva Laxmạ̣ S'âstrî Paṇsîkar (eds.). 1916. The Kâdambarî of Bânabhatta and His Son (Bhûshaṇabhatta) With the Commentaries of Bhânuchandra and His Disciple Siddhachadra (Proteges of the Emperor Akbar). Fifth Edition. Bombay. Nirnaya-sagar Press.

Pasedach, Peter. 2017. "Bhagavatstutivarnana or the Description of the Praise of the 
Divine. A Critical Edition of Text and Commentaries, and Annotated Translation of the Sixth Canto of Ratnākara's Haravijaya." PhD dissertation, University of Hamburg.

Pelliot, Paul. 1959-1973. Notes on Marco Polo. Ouvrage Posthume publié sous les auspices de l'Académie des Inscriptions et Belles-Lettres et avec le concours du Centre national de la Recherche scientifique. 3 vols. Paris: Imprimerie Nationale, Librairie AdrienMaisonneuve.

Penzer, Norman Mosley (ed.). 1925. The Ocean of Story. Being C.H. Tawney's Translation of Somadeva's Kathā Sarit Sāgara. Vol. iv. Foreword by Dr. F.W. Thomas. London: Charles J. Sawyer, Ltd., Grafton House.

Peterson, Peter (ed.). 1889. Kâdambarî by Bâna \& his son. Vol. I. containing the Sanskrit text. Bombay Sanskrit Series XxIv. Bombay: Government Central Book Depot.

Qaddūmī, Ghāda al Hiijjāwī al-. 1996. Book of Gifts and Rarities (Kitāb al-Hadāyā wa al-Tuhaf). Selections Compiled in the Fifteenth Century from an Eleventh-Century Manuscript on Gifts and Treasures. Harvard Middle Eastern Monographs 29. Cambridge MA: Harvard University Press.

Ray, Joges Chandra. 1917. "Textile Industry in Ancient India." Journal of the Bihar and Orissa Research Society 3/2: 180-245.

Rajappa, Padmini (trans.). 2010. Bana. Kadambari. New Delhi: Penguin Books India.

Rāmaswāmī, K.S. Śāstri Śiromaṇi (ed.). 193o. Rāmacarita of Abhinanda Critically edited with an introduction. Gaekwad's Oriental Series No. 46. Oriental Institute: Baroda.

Roberts, Peter Alan and Tulku Yeshi (trans.). 2013. The Noble Mahāyāna Sūtra "The Basket's Display". 8400o: Translating the Words of the Buddha. https://read.8400o .co/translation/toh116.html (last accessed on May 19, 2020).

Ross, Malcolm and Robert P. Nolan. 2003. "History of asbestos discovery and use and asbestos-related disease in context with the occurrence of asbestos within ophiolite complexes." In Dilek, Yildirim and Sally Newcomb (eds.), Ophiolite Concept and the Evolution of Geological Thought. The Geological Society of America Special Paper 373. Boulder CO: Geological Society of America, pp. 447-470.

Samasrami, Satyabrata. 1873. Kāraṇdaryūhasūtra. The Hindu Commentator vol. 5. Calcutta.

Sanderson, Alexis. 2007. "The Śaiva Exegesis of Kashmir." In Dominic Goodall and André Padoux (eds.), Mélanges tantriques à la mémoire d'Hélène Brunner/Tantric Studies in Memory of Hélène Brunner. Pondicherry: Institut Français de Pondichéry/École française d'Extrême-Orient, pp. 231-442 \& 551-582.

S'arma, Nanda Kishore (ed.). 1932. The Nalachampu or Damayantī Kathā with the Vișamapada Prakās'a Commentary by Chaṇdapāla. The Kâshi-Sanskrit-Series 98. Benares: Chowkhambha Sanskrit Series Office.

Sauvaget, Jean. 1948. 'Ahbār aṣ-Șin wa l-Hind. Relation de la Chine et de l'Inde rédigée en 851. Text établi, traduit et commenté. Paris: Société d' édition "Les Belles Lettres". 
Scharpé, Adriaan Alberik Maria. 1937. Bāṇa's Kādambarī. Vertaling, van het Sanskrit in het Nederlands, van het Uttarabhāga en van gedeelten van het Pūrvabhāga, met inleiding, aantekeningen en lexicographisch appendix. Proefschrijft, Rijksuniversiteit te Utrecht. Leuven: N.V. de Vlaamsche Drukkerij.

Schmidt, Richard. 1928. Nachträge zum Sanskrit-Wörterbuch in kürzerer Fassung von Otto Böhtlingk. Leipzig: Verlag von Otto Harrassowitz.

Seyfort Ruegg, David. 1971. "Le Dharmadhātustava de Nāgārjuna." In Études tibétains dédiées à la Memoire de Marcelle Lalou. Paris: Librairie d'Amerique et de l'Orient, pp. 448-471.

Sferra, Francesco. 2005. "Constructing the Wheel of Time. Strategies for Establishing a Tradition." In Federico Squarcini (ed.), Boundaries, Dynamism and Construction of Traditions is South Asia. Firenze: Firenze University Press and Munshiram Manoharlal, pp. 253-285.

Sferra, Francesco. 2006. The Sekoddeśațīkā of Nāropā (Paramārthasamgraha). Serie Orientale Roma cxıx. Rome: Istituto Italiano per l'Africa e l'Oriente.

Sferra, Francesco. 2015. "Kālacakra." In Jonathan A. Silk et al. (eds.), Brill Encyclopedia of Buddhism, volume 1. Leiden: Brill, pp. 341-352.

S’ivadațta, Pandit and Kâshînâth Pândurang Parab (eds.). 19o1. Bṛhatkathâmañjari of Kṣemendra. Kâvyâmâlâ 69. Bombay: Nirṇaya-sâgara Press.

Silk, Jonathan A. 2020. "A Resurgent Interest in "Hindu Fiction". On and around the Kathāsaritsāgara with Special Attention to Buddhism." Indo-IranianJournal 63:263306.

Silverberg, Robert. 1972. The Realm of Prester John. Athens, OH: Ohio University Press.

Sircar, Dinesh Chandra. 1979. Aśokan Studies. Indian Museum Monograph No. 11. Calcutta: Indian Museum.

Srivastava, Uma. 1979. "An edition of Arjuna-Paṇdita's commentary on the Kādambarī (Uttarabhāga) (with an introduction and notes in English)." PhD dissertation, University of Toronto.

Śrīcaraṇavijaya, Munirāj Mahārāj (ed.). 199o. Kalikālasarvajña Śrīhemacandrācāryaviracitam Triṣaștiśalākāpuruṣacaritamahākāryam. Prathamam parva. Ahmedabad: Kalikālasarvajña Śrīhemacandrācārya navama janmaśatābdī smṛti śikṣaṇa-saṃskāranidhi.

Stein, Marc Aurel [Márk Aurél]. 1892-19oo. Kalhaṇa's Rājatarañgin̄i: a Chronicle of the Kings of Kaśmìr. Translated with an Introduction, Commentary, and Appendices, Vol. I. Introduction. Books I.-VII. Vol. II Book VIII with Notes, Geographical Memoir, Index, Maps. Volume III Critical Notes. Westminster: Archibald Constable and Company, Ltd.

Steiner, Roland. 2020. "Woher hat er das? Zum Charakter des Sanskrit-English Dictionary von Monier-Williams." Zeitschrift der Deutschen Morgenländischen Gesellschaft 170.1: 107-117. 
Sukthankar, V.S. et al. 1927-1959. The Mahābhārata. For the first time critically edited. 19. vols. Poona.

Studholme, Alexander. 2002. The Origins of Oṃ Maṇipadme Hūṃ. A Study of the Kāraṇdaryūha Sūtra. Albany NY: State University of New York Press.

Sykes, Percy. 1915. A History of Persia. Volume I. London: Macmillan \& Co. Ltd.

Szántó, Péter-Dániel. 2012. "Selected Chapters from the Catuṣpițhatantra. Volume 1: Introductory study with the annotated translation of selected chapters." DPhil dissertation, University of Oxford.

Szántó, Péter-Dániel. 2015a. "Minor Vajrayāna Texts III: A Fragment of the *Guhyasamājoddhrtayāgavidhi." In Ramble, Charles and Ulrike Roesler (eds.), Tibetan and Himalayan Healing: an Anthology for Anthony Aris. Kathmandu: Vajra Publications, pp. $667-686$.

Szántó, Péter-Dániel. 2015b. “Azbeszt és szalamandra Indiában." In Kakas, Beáta and Zsolt Szilágyi (eds.), Kéklő hegyek alatt lótuszok tava: Tanulmányok Bethlenfalvy Géza tiszteletére / Lotus Lake under Blue Mountains: Essays in honour of Géza Bethlenfalvy. Budapest: L'Harmattan, pp. 107-118.

T = Taishō Tripițaka https://21dzk.l.u-tokyo.ac.jp/SAT/

Tōhoku = The sDe dge print of the Tibetan Canon, reference nos. according to Hakuju Ui, Munetada Suzuki, Yenshô Kanakura, and Tôkan Tada (eds.). 1934. A Complete Catalogue of the Tibetan Buddhist Canons (Bkah-hgyur and Bstan-hgyur). Sendai: Tôhoku Imperial University.

Tripāțhī, Kailāspati (ed.). 1976. The Nalachampù or Damayantī-Kathā of Śrī Trivikrama Bhațta with The Vișamapada Prakāśa Sanskrit Commentary by Śrī Chaṇdapāla (1260 A.D.) Edited with His Own Commentary (1-2 Chapters). Third edition. The Kashi Sanskrit Series 98. Varanasi: Chaukhambha Sanskrit Sansthan.

Tubb, Gary. 2014. "Something New in the Air: Abhinanda's Rāmacarita and Its Ancestry." In Yigal Bronner, David Shulman, and Gary Tubb (eds.), Innovations and Turning Points: Toward a History of Kārya Literature. Oxford: Oxford University Press, pp. 357-394.

Upadhyaya, Jagannath (ed.), Vimalaprabhāțīkā of Kalki Śrī Pundarīka on Śrī Laghukālacakratantrarāja by Śrī Mañjuśrīyaśa [vol. ı.]. Bibliotheca Indo-Tibetica Series No. XI. Sarnath: Central Institute of Higher Tibetan Studies.

Vaidya, Paraśurām Lakșmạ̣ (ed.). 1961. Mahāyāna-sūtra-Saṃgraha. Part I. Buddhist Sanskrit Texts Series No. 17. Darbhanga: The Mithila Institute of Post-Graduate Studies and Research in Sanskrit Learning.

Vasu, Śrīvaradāprasāda and Śrīharicaraṇa Vasu (eds.). 1886. Śabdakalpadrumaḥ syārarājā-rādhākāntadeva-bāhādureṇa viracitaḥ. Calcutta.

Vidyasagara, Pandit Jibananda (ed.). 1884. Balaramayana, a Drama by Rajasekhara Edited with a Commentary. Calcutta: New Valmiki Press.

Vogel, Hans Ulrich. 2013. Marco Polo Was in China. New Evidence from Currencies, Salts 
and Revenues. Monies, Markets, and Finance in East Asia, 1600-19oo 2. Leiden: Brill.

Vogel, Jean Philippe. 1957. "Errors in Sanskrit Dictionaries." Bulletin of the School of Oriental and African Studies, University of London 20, no. 1/3: 561-567.

Wayman, Alex. 1977. Yoga of the Guhyasamājatantra. The Arcane Lore of Forty Verses. A Buddhist Tantra Commentary. Buddhist Traditions vol. xvir. Delhi: Motilal Banarsidass.

Weber, Albrecht. 1878. Indische Studien. Beiträge für die Kunde des indischen Alterthums. Funfzehnter Band. Leipzig: F.A. Brockhaus.

Wood, Frances. 1996. Did Marco Polo Go to China? Boulder, CO: Westview Press.

Wylie, A. 1897. "Asbestos in China." Chinese Researches. Shanghai, pp. 141-154.

Yang, Han-sung, Jan Yün-hua, Iida Shotaro, and Laurence W. Preston (eds. and trans.). 1984. The Hye-ch'o diary: Memoir of the Pilgrimage to the Five Regions of India. Religions of Asia Series 2. Seoul: UNESCo Collection of Representative Works.

Yokochi, Yuko. 2004. "The Rise of the Warrior Goddess in Ancient India. A Study of the Myth Cycle of Kauśikī-Vindhyāvāsinī in the Skandapurāṇa." PhD dissertation, University of Groningen. 